\title{
Identitas Sosial dan Hedonisme di Laman Pribadi Selebgram
}

\author{
Natasya Intan $P_{.}^{a, 1}$, Mutia Rahmi Pratiwi ${ }^{\mathrm{b}, 2^{*}}$, dan Nalal Muna ${ }^{\mathrm{c}, 3}$ \\ ${ }^{\mathrm{ab}}$ Universitas Dian Nuswantoro dan ${ }^{\mathrm{c}}$ Politeknik APP Jakarta \\ Email: ${ }^{1}$ natasyaintan07@gmail.com, ${ }^{2}$ mutia.rahmi@dsn.dinus.ac.id*, dan ${ }^{3}$ nalal@kemenperin.go.id \\ *corresponding author
}

Keywords:

hedonism, influencer, instagram, social identity, selebgram.

\section{Kata Kunci:}

hedonisme, influencer, instagram, identitas sosial, selebgram.

\begin{abstract}
Social media users tend to be "the center of attention". One of the social media that is widely used in Indonesia is Instagram and people who are popular on Instagram are called celebrities. Karin, through her Instagram account@ awkarin, is one of the celebrities who appeared in 2018 with a controversial and hedonistic lifestyle. This research is qualitative research using the virtual ethnography method. The research object analyzed was the upload on the @ awkarin page during 2019 which contained elements of hedonism. The theory used is the theory of identity presented by Tajfel and the theory of hedonism. The results showed that Karin through the@awkarin Instagram account has formed a virtual social identity by displaying personal orientation, individual values, and self-expression. The form of hedonism that refers to Awkarin on Instagram includes three things, namely: Activities, Interests, and Opinions. Hedonistic activities are shown by hangout, owning luxury items, and going with friends or partners to a cafe or fancy place. Karin's interest is shown by the items used and gathered in a special place for the middle and upper social classes. Karin's opinion is shown with comments to netizens who are pro and contra.
\end{abstract}

\begin{abstract}
ABSTRAK
Pengguna media sosial memiliki kecenderungan untuk menjadi "pusat perhatian". Salah satu media sosial yang banyak digunakan di Indonesia adalah Instagram dan orang yang populer di Instagram disebut selebgram. Karin melalui akun Instagram @awkarin merupakan salah satu selebgram yang muncul di tahun 2018 dengan kontroversial dan bergaya hidup hedonisme. Penelitian ini merupakan penelitian kualitatif dengan metode etnografi virtual. Objek penelitian yang dianalisis adalah unggahan pada laman@awkarin selama tahun 2019 yang mengandung unsur hedonism. Teori yang digunakan adalah teori identitas yang disampaikan oleh Tajfel dan teori hedonisme. Hasil penelitian menunjukan bahwa Karin melalui akun Instagram@awkarin telah membentuk identitas sosial secara virtual dengan menampilkan orientasi pribadi, nilai individu dan ekspresi diri. Bentuk hedonisme yang mengacu pada awkarin di Instagram mencakup tiga hal, yaitu: Aktivitas, Minat dan Opini. Aktivitas hedonisme ditunjukan dengan hangout, memiliki barang mewah dan pergi bersama teman-teman atau pasangan ke kafe atau tempat dengan kesan mewah dan mahal lainnya. Minat Karin ditunjukan dengan barang yang digunakan dan berkumpul di tempat khusus untuk kelas sosial menengah keatas. Opini Karin ditunjukan dengan komentar kepada netizen yang pro maupun yang kontra.
\end{abstract}

Copyright (C) 2020 Channel Jurnal Komunikasi. All right reserved. 


\section{PENDAHULUAN}

Teknologi terus berkembang di berbagai bidang terutama komunikasi di sektor keberagaman media digital diantaranya platform media sosial. Menurut Van Dijk (2013: 12), media sosial yang digunakan para penggunanya semakin melunturkan ruang privasi seseorang karena aktivitas kegiatan manusia yang tidak pernah lepas dari penggunaan sosial media. Dampak beragam ditimbulkan para pengguna media sosial diantaranya rasa ingin tahu yang semakin tinggi dan penggunaan fitur terbaru yang kemudian menjadi tanda identitas kekinian ketika diunggah di akun media sosialnya. Individu sebagai pengguna media sosial difasilitasi untuk bisa menunjukkan dirinya sebagai "center of attention" atau pusat perhatian bagi orang lain. Dari banyaknya media sosial, yang saat ini paling banyak digunakan adalah Instagram. Hasil riset dari We Are Social (2019) menunjukkan pengguna media Instagram kini mencapai 62 Milyar pada Januari 2019 dan menjadi urutan ketiga dalam social network yang sangat sering digunakan (mencapai 80\%). Perkembangan Instagram menjadikan penggunanya semakin merasa memiliki ruang virtual yang menyenangkan untuk bercerita secara langsung melalui berbagai unggahan yang diinginkan sehingga menarik perhatian orang lain untuk memberi respon seperti like dan comment.

Ada berbagai dampak yang muncul dari kebebasan mengunggah aneka konten di Instagram, salah satunya adalah sifat narsisme yang terlihat dari tampilan instastory maupun feed penggunanya. Freud menyatakan bahwa narsisme merupakan rasa cinta kepada diri sendiri yang akhirnya membentuk sikap mementingkan dirinya sendiri (Alwisol, 2011: 19). Orang dengan kecenderungan narsisme ditunjukan dengan tingginya intensitas publikasi aktivitas keseharian di laman media sosialnya sehingga orang lain akan melihat hingga menjadi follower yang terus mengikuti perkembangan unggahan setiap harinya. Pelaku narsisme memiliki kecenderungan berlomba mengunggah potret dirinya atau bersama dengan teman dekat atau lingkup terdekatnya dengan tujuan mendapat atensi publik (berupa like dan comment). Dampak lainnya adalah munculnya gaya hidup hedonisme yang nampak dari unggahan-unggahan yang muncul dari feed penggunanya maupun instastory yang terus menerus di update.

Pengguna Instagram yang populer dengan jumlah unggahan dan follower yang cukup tinggi dapat dikategorikan sebagai seorang "selebriti Instagram" atau Selebgram. Para selebgram dengan ciri khasnya yang sesuai dengan segmentasinya akan menjadi role model atau public figure yang terus diamati hingga ditiru. Selebgram dapat didefinisikan segmentasinya berdasar pada tampilan profil dan konsistensi konten yang diunggah, misalnya: family activity, daily activity, travelling, hobi tertentu hingga gaya hidup yang menunjukan modernitas. Berdasar hasil observasi yang dilakukan peneliti, para selebgram memiliki banyak cara dalam menarik atensi pengguna media sosial diantaranya dengan mengunggah konten kontroversial. Salah satu selebgram yang mengundang banyak atensi adalah Karin Novilda atau Awkarin yang populer pada awal kemunculannya sebagai influencer yang buruk.

Awkarin adalah seorang selebgram dengan followers lebih dari 5,2 juta orang. Media sosial @awkarin berisi kumpulan gaya hidup berupa foto-foto bahkan video yang menampilkan bagaimana fashion, style dan kehidupan seharihari Karin Novilda. Berdasarkan hasil observasi peneliti, lebih dari 80\% dalam tampilan foto feed di Instagram, Karin selalu mengenakan pakaian yang terbuka dengan memperlihatkan lekuk tubuhnya dan didukung dengan gaya vulgar. Karin juga menunjukan dirinya memiliki gaya hidup yang terkesan hedonis namun tampilan-tampilan Awkarin justru menunjukan dampak positif dari para followersnya, yaitu: banyaknya like dan komentar yang menyenangkan seperti menyatakan keren, baik bahkan menjadikannya idola kesayangan. Gaya busana Karin yang terkesan nakal, tetapi terlihat asik, santai, keren, dan trendy menjadikannya seorang gadis dengan selera fashion tinggi di mana hal ini menjadi trendsetter bagi remaja milenial masa kini. Berikut ini adalah tampilan profil Instagram Awkarin:

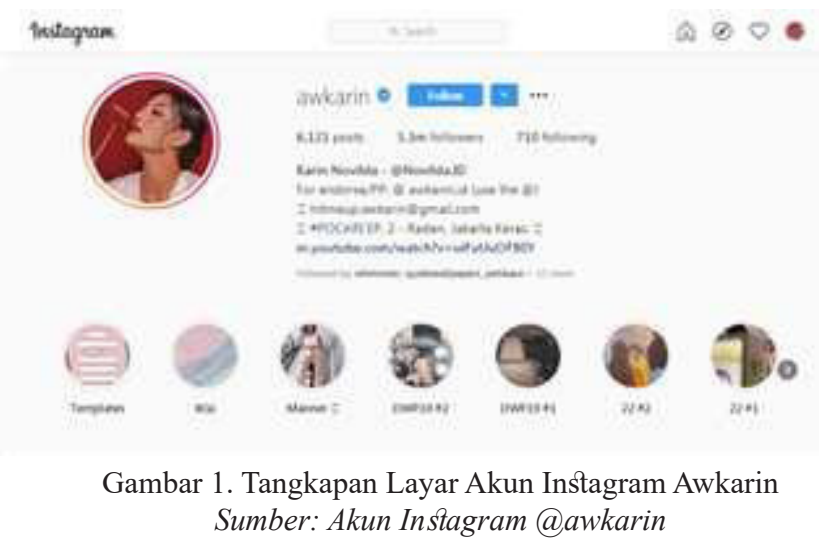

Penelitian ini dilakukan dengan mengamati unggahan-unggahan Karin di feed Instagram@awkarin selama satu tahun, yaitu pada tahun 2019. Adapun beberapa alasan mengapa akun@awkarin layak menjadi subjek penelitian adalah: Influencer dalam sosial media, bergabung dengan sosial media Instagram sejak 2013, Memiliki Followers di atas 
5.000.000, Konten yang telah di upload lebih dari 5.000 postingan, Aktif dalam sosial media Instagram dan memperoleh atensi penyuka lebih dari 50.000 .

Tampilan diri yang muncul di media sosial menunjukan eksistensi diri dengan tujuan mendapatkan perhatian yang besar dari publik. Hal ini karena manusia memiliki kebutuhan untuk bersosialisasi dan mendapat penghargaan dari apa yang telah dilakukan, termasuk penghormatan. Tampilan diri di media sosial merupakan proses pemilahan yang diinginkan oleh pemilik akun tersebut dengan tujuan yang diinginkan dengan menunjukan simbol prestige yang dimiliki. Tidak dapat dipungkiri bahwa unggahan diri di laman media sosial akan menciptakan identitas diri secara virtual yang bisa saja berbeda dengan dunia nyata atau bahkan saling mendukung dengan dunia nyata. Persoalan identitas dan unggahan pribadi di laman media sosial terus berkembang secara dinamis dan mudah dibentuk sesuai tujuan yang diharapkan. Hal ini juga terjadi pada Karin sebagai pemilik akun@awkarin.

Penelitian-penelitian terkait dengan identitas virtual maupun gaya hedonisme di media Instagram telah dilakukan oleh peneliti lainnya. Penelitian terkait identitas virtual telah dilakukan oleh Witri dan Pratiwi pada tahun 2019 menunjukan bahwa terdapat lima aspek pengungkapan diri yang dilakukan oleh informan di laman media sosial, yaitu: aspek ketepatan, motivasi, waktu, keintensifan dan kedalaman. Penelitian lainnya terkait identitas virtual telah dilakukan oleh Hatmi P pada tahun 2018 yang menunjukan bahwa para informan melakukan aktivitas roleplay untuk pemenuhan kebutuhan akan hasrat fanatisme terhadap sang idola dan merasa telah meraih potensi yang diinginkan melalui representasi diri dan membuat identitas virtual baru di dunia maya. Penelitian terkait hedonisme telah dilakukan oleh Wijayanti pada tahun 2018, yang membuktikan bahwa gaya hidup hedonisme disebabkan oleh kolektivitas dalam komunikasi individu. Instagram seseorang dipengaruhi oleh pengguna lainnya yang diikuti oleh lingkungan visual yang sama sehingga muncul ekspektasi yang sama.

Berdasar pada referensi penelitian terdahulu, perbedaan signifikan pada penelitian ini adalah perbedaan objek penelitian dan tujuan penelitian. Pada penelitian sebelumnya menekankan pada peranan kelompok dalam menunjukan hedonisme yang berakibat pada diikuti secara personal. Dapat disimpulkan bahwa dari tiga penelitian terdahulu mengambil dari sudut pandang pengguna media sosialnya namun bukan dari sudut pandang konten selebgram yang seringkali mendapat banyak atensi. Penelitian ini bertujuan untuk mendeskripsikan bentuk hedonisme yang ditampilkan selebgram Karin melalui akun Instagram@awkarin. Metode penelitian yang digunakan adalah etnografi virtual di mana hasilnya akan dianalisa menggunakan teori identitas sosial dan teori hedonisme.

\section{METODE PENELITIAN}

Penelitian ini merupakan jenis penelitian kualitatif dengan menggunakan metode etnografi virtual. Penelitian kualitatif bertujuan untuk memahami fenomena yang dialami subjek penelitian secara utuh dengan mendeskripsikannya dalam bentuk bahasa (Moleong, 2009:33). Etnografi merupakan penelitian yang melibatkan etnografer untuk mengamati apa yang terjadi dalam keseharian kehidupan masyarakat (Bate, 1997). Penelitian yang mengeksplorasi dunia digital disebut netnografi atau disebut etnografi virtual (Kozinets, 2002). Etnografi virtual dilakukan dengan tujuan melihat fenomena sosial atau budaya pengguna di ruang virtual (Nasrullah, 2014:171). Hine mengungkapkan bahwa dalam etnografi virtual, fenomena yang diangkat merupakan hanya merupakan satu bagian dan tidak menggambarkan bagaimana sesungguhnya kehidupan di media digital itu berlangsung (Hine, 2000: 63-65). Etnografi virtual berpusat pada komunikasi berbasis teks sebagai fokus penelitian (Kozinets, 2002). Tahapan dalam etnografi virtual adalah : peneliti bertindak sebagai pengamat yang mengambil data di media digital secara secara terperinci, identifikasi pola, melakukan kajian literatur untuk menganalisis teks (Hurley, 1998).

\section{HASIL DAN PEMBAHASAN}

\section{A. Identitas Sosial pada Laman akun@awkarin}

Teori identitas sosial menyatakan bahwa orang cenderung mengklasifikasikan dirinya dan orang lain ke dalam berbagai kategori sosial yang tersedia. Hal ini merupakan cara untuk menentukan identitas diri dan adanya rasa kepemilikan seseorang terhadap sekelompok atau sekumpulan manusia yang lebih besar (Ashforth \& Mael, 1989; Tajfel \& Turner, 1986). Kategori sosial dapat dikategorikan berdasar pada jenis kelamin, agama yang dianut, kelompok usia, dan keanggotaan dari suatu organisasi berbasis pada tujuan bersama yang dimiliki (Tajfel \& Turner, 1986).

Di dalam konsep teori identitas sosial terdapat grup yang bertujuan agar para anggotanya merasakan dirinya bagian dari asosiasi atau disebut "in group" dan untuk orang lain yang berada pada kelompok lainnya seringkali disebut sebagai "out group" (Tajfel, 1982). Ketika seseorang berusaha untuk memaksimalkan harga diri mereka, maka seseorang akan terus berupaya untuk memaksimalkan konsep diri mereka untuk dapat diterima baik dalam kelompoknya dan dianggap tidak baik oleh kelompok diluar dari kelompoknya (Tajfel, 1982).

Pada laman Instagram @awkarin, Karin menampilkan dirinya sebagai Remaja Milenial kekinian yang memiliki banyak teman dengan Social Economic Status menengah ke atas. Hal ini ditunjukan dengan lebih dari 60\% unggahan Awkarin berlatar belakang simbol-simbol kemewahan yaitu: kafe mahal, hotel berbintang, mobil mewah, dan fashion 
branded. Karin juga tak segan menunjukan kemesraan dengan kekasihnya dengan suasana romantisme yang mendukung seperti di pantai, di hotel atau lokasi romantis lainnya. Dalam unggahannya di feed, Karin tergambarkan sebagai teman bersenang-senang yang menyenangkan karena seringkali menampilkan kedekatan dengan kelompoknya saat berpesta bersama atau kegiatan kebersamaan lainnya. Berdasar teori identitas sosial, lingkungan berkontribusi besar dalam membentuk konsep diri seseorang dan menunjukan bagaimana terbentuknya jaringan kelompok yang memiliki kecenderungan sama dengan dirinya. Berikut unggahan foto di feed Instagram Karin yang menunjukan identitas sosialnya:
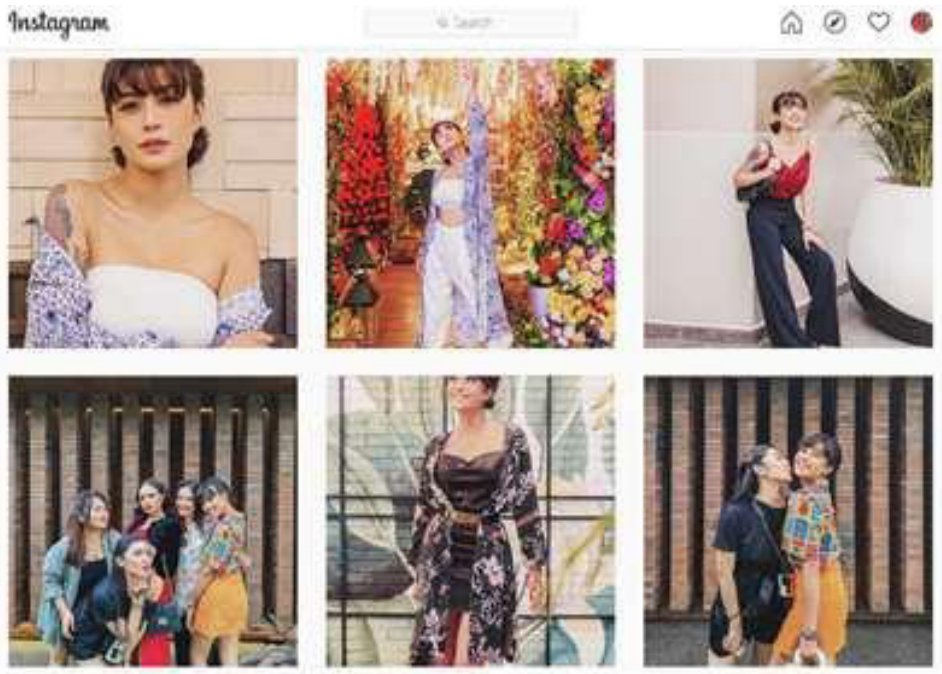

Gambar 2. Tampilan feed @awkarin yang menunjukan identitas sosial Sumber: AkunInstagram@awkarin

Karakter individu yang dipengaruhi kolektivistik dalam komunikasi individu (Widya Rini, 2009: 11):

1. Personality Orientations (Orientasi Personal), menggambarkan bagaimana orientasi personal dalam berkomunikasi dengan orang lain.

2. Individual Values (Nilai-nilai Individu), yaitu nilai-nilai personaliti yang dimiliki individu untuk mempertahankan dan menjaga kepercayaan diri seseorang ketika melakukan komunikasi

3. Self Contractuals (penyingkapan diri/ekspresi diri), menggambarkan bagaimana individu mengekspresikan dirinya kepada individu lain ketika berkomunikasi.

\section{B. Orientasi Personal pada laman Instagram@awkarin}

Orientasi Personal yang ingin ditunjukan Karin di laman Instagramnya adalah seorang remaja muda yang keren dan berani. Definisi keren adalah ketika seseorang dengan berani dan percaya diri menunjukan jati diri yang sesungguhnya melalui gaya berpakaian yang membuatnya nyaman walaupun ia menyadari bahwa yang dilakukannya seringkali berbeda dengan keadaan normatif. Keberanian Karin ditampilkannya di Instagram ditunjukan melalui tampilan foto dengan pakaian yang cenderung terbuka, pemilihan caption terkesan blak-blakan dan berani memberikan balasan komentar yang cenderung kasar. Berbagai simbol juga turut menekankan orientasi personal yang dipilih oleh Karin, seperti: gaya hidup bebas, rokok dan minuman beralkohol. Notabene perempuan Indonesia seringkali digambarkan sebagai perempuan yang selalu menjaga ucapan dan sikapnya namun hal ini serigkali bertolak belakang dengan apa yang ditampilkan Karin di laman Instagramnya.

Berikut ini contoh tampilan Orientasi Personal@awkarin:
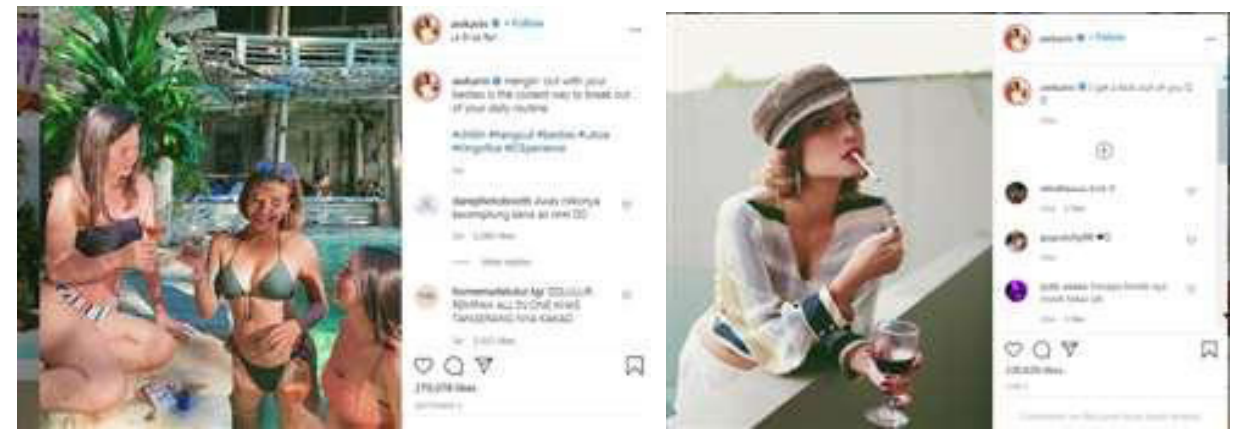

Gambar 3. Tampilanfeed @awkarin yang menunjukan orientasi personal Sumber:AkunInstagram@awkarin 


\section{Nilai Individu pada laman Instagram @awkarin}

Nilai individu yang ditampilkan Karin di akun Instagramnya adalah menjadi orang jujur sesuai yang diinginkan dirinya. Karin menunjukan gaya hidup hedonisnya dengan menampilkan foto saat mengkonsumsi minuman beralkohol bahkan menunjukan gaya seks bebas dengan pergi bersama kekasihnya yang didukung oleh foto-foto yang yang menunjukan keintiman. Berikut contoh salah satu unggahannya:

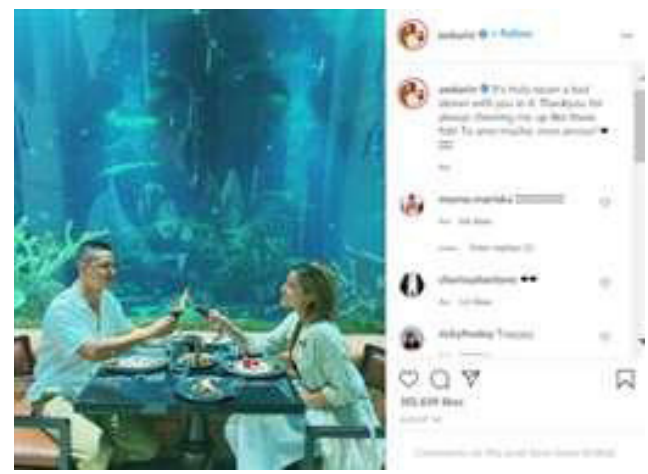

Gambar 4. Tampilan feed @awkarin terkait Orientasi Personal Sumber: Akun Instagram @awkarin

Karin juga menunjukan sisi kolektivitas pada saat foto bersama teman-temannya ketia ia mengadakan pesta ulang tahun dan saat kegiatan berlibur bersama teman-temannya. Ekspresi diri yang ditampilkan melalui akun Instagramnya @awkarin menunjukan bahwa Karin adalah pribadi yang open minded, setia dan memiliki solidaritas yang tinggi dengan teman. Berdasar jumlah unggahan, Karin tergolong influencer yang aktif mengunggah konten di mana hal ini terlihat dalam satu tahun unggahannya mencapai lebih dari 100 unggahan.

\section{Hedonisme dan Media Sosial Selebgram}

Awalnya, istilah hedonisme digunakan pada tahun 1781 oleh Jeremy Bentham (Salam, 2000: 222). Hedonisme berasal dari bahasa Yunani "Hedone” yang berarti kesenangan. Terdapat tiga versi hedonism, yaitu aksiologis (adanya nilai intrinsik yang mengikuti), hedonisme psikologis (tindakan yang dilakukan bertujuan dan berasal dari kesenangan), dan hedonisme etis (kebenaran moral berdasar pada tujuan dari tindakan kesenangan yang dilakukan) (Tilley, 2012: 66).

Dari beberapa unggahan di akun Instagramnya, Karin menunjukan kesenangan yang dia rasakan saat bekerja di Bali melalui foto yang ditampilkan yaitu dirinya sedang menikmati berendam di kolam renang dengan bikini dengan ekspresi bahagia dan didukung dengan caption: "Belum Pernah sebelumnya ngerasain ke Bali 6 hari full tapi gak liburan- Full kerja. Dan ngerasain dapet liburan yang bener-bener liburan tanpa mikirin kerjaan Cuma 4 jam, Im so blessed!!’. Hal ini merupakan implementasi dari salah satu konsep teori Hedonism yang dinyatakan oleh J.S Mills bahwa kebahagiaan merupakan satu-satunya hal yang diinginkan oleh seseorang untuk kepentingan dirinya dan akan mendatangkan kesenangan yang instrinsik (Tilley, 2012: 568).

Hedonisme merupakan ajaran atau pandangan tujuan dari kehidupan dan tindakan yang dilakukan oleh diri sebagai manusia adalah kesenangan atau kenikmatan yang dirasakan (Lorens, 2000: 282). Karin yang memiliki sebutan selebgram atau influencer yang mendapat popularitas melalui Instagram, memiliki pengikut dan memiliki kemampuan untuk membuat konten yang menarik dengan dengan kekhasan dirinya. Ketika seseorang memiliki gaya hidup hedonis yang diunggah di laman Instagram pribadi maka ada unsur keinginan diri untuk memperoleh pengakuan dari gaya hidup yang mereka dipilih dan dijalani di mana hal ini juga ditunjukan oleh Karin. Seseorang dengan gaya hidup hedonism cenderung memiliki nilai kenikmatan, harta benda, dan hiburan, seperti foto yang diunggah pada 5 dan 10 Februari 2019 lalu berikut ini:
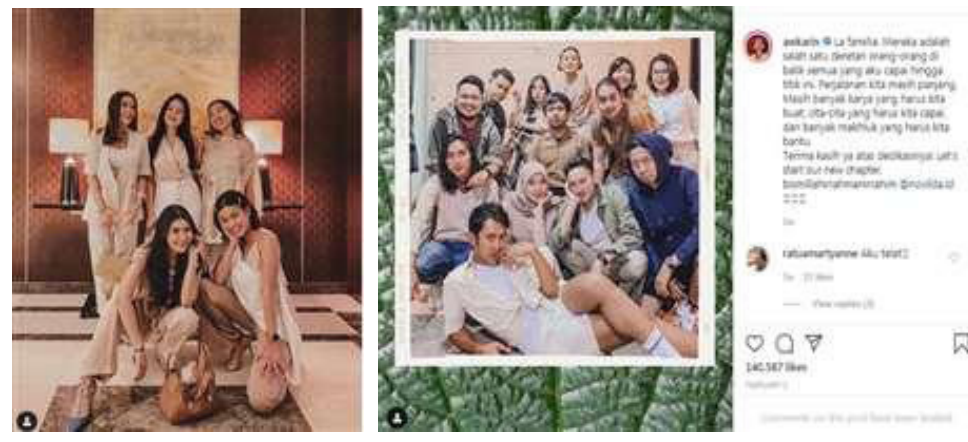

Gambar 5. Feed tentang gaya hidup hedonis Awkarin bersama kelompoknya. Sumber: AkunInstagram@awkarin 
Penelitian yang dilakukan oleh Puspitasari pada tahun 2015 menyatakan bahwa adanya suatu kebutuhan yang mendorong individu untuk mengunggah potret diri di laman media sosial yaitu faktor eksplanasi diri di mana ada kebutuhan untuk menunjukan dukungan terhadap orang lain, menunjukan tampilan diri yang menarik dan kebutuhan untuk menjalin relasi dengan orang lain. Gaya hidup yang dipilih dan dijalani oleh seseorang dengan orang lain bisa saja sama bahkan sebaliknya. Gaya hidup merupakan gambaran kehidupan personal yang dialami, kehidupan masyarakat, perilaku atau sikap yang ditunjukan di depan umum, serta adanya upaya untuk membedakan status diri dengan menekankan lambanglambang sosial. Amstrong (2003 : 15) menyatakan bahwa gaya hidup hedonis adalah suatu pola hidup yang aktivitasnya untuk mencari kesenangan hidup, termasuk melakukan kegiatan di luar rutinitas monoton seperti menghabiskan waktu diluar rumah, bermain bersama peer group bermain, menikmati keramaian kota, merasa puas saat membeli barang mahal yang memiliki simbol tertentu, serta selalu ingin menjadi pusat perhatian.

Semakin bertambahnya zaman akan beriringan dengan pesatnya perkembangan teknologi yang secara langsung akan berimbas pada penerapan gaya hidup oleh manusia karena mereka adalah user of technology. Berikut ini adalah aspek-aspek gaya hidup hedonisme:

1. Kegiatan (Activities)

Tindakan nyata yang ditunjukan. Misalnya: banyak menghabiskan waktu diluar rumah, lebih banyak membeli barang-barang yang kurang diperlukan, pergi ke pusat perbelanjaan dan kafe.

2. Minat (Interest)

Minat dapat ditunjukan melalui berbagai hal yang tampak seperti fashion dan makanan yang menunjukan kelas tertentu, penggunaan barang-barang mewah, tempat kumpul, dan keinginan untuk selalu menjadi pusat perhatian.

3. Opini (Opinion)

Opini merupakan jawaban yang disampaikan secara lisan atau tertulis yang diberikan sebagai respon terhadap situasi tertentu untuk mendeskripsikan pemikiran, harapan, dan evaluasi dalam perilaku.

Hasil penelitian menunjukan bahwa Karin melalui akun Instagramnya menggambarkan diri dengan aktivitas hedonis yang diarahkan melalui kesenangan serta memilih kelompok sosial menengah ke atas. Beberapa karakteristik gaya hidup hedonisme menurut Rahardjo dan Silalahi (2007: 34) yaitu pada umumnya hidup dan tinggal di kota besar, di mana hal ini tentu saja berkaitan dengan kesempatan akses informasi, secara jelas akan mempengaruhi gaya hidup, berasal dari kalangan berada dan memiliki banyak uang karena banyaknya materi yang dibutuhkan sebagai penunjang gaya hidup, mengikuti perkembangan fashion di majalah-majalah mode agar dapat mengetahui perkembangan mode terakhir yang gampang diikuti, umumnya memiliki penampilan yang modis, trendy dan sangat memperhatikan penampilan. Berikut ini merupakan beberapa contoh pilihan fashion yang digunakan Karin dan diunggah dalam akun Instagramnya:

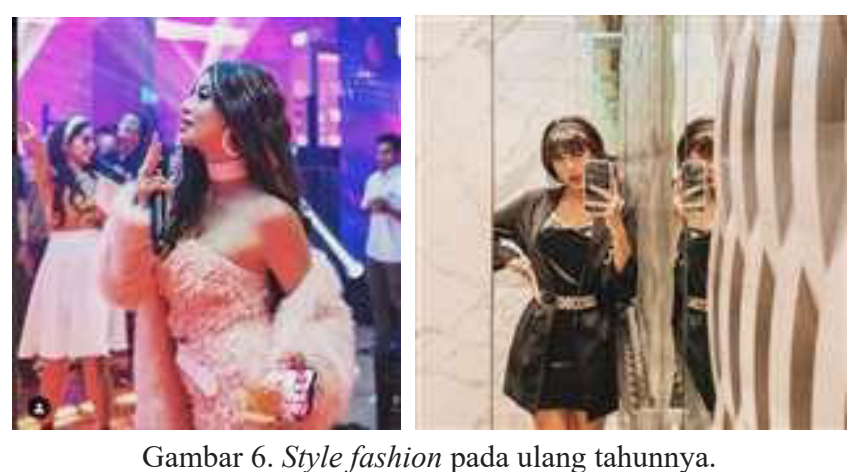

Gambar 6. Style fashion pada ulang tahunnya.

Sumber:AkunInstagram@awkarin

Gambar di atas merupakan salah satu contoh dari gaya Awkarin yang hedonis dalam Instagram. Postingan yang diunggah pada tanggal 27 November dan 3 Desember 2019 merupakan gaya fashion Awkarin pada saat ulang tahunnya yang ke-22 dengan bertemakan back to 80's. Gaya glamour yang ditampilkan Awkarin dalam postingan ini terlihat dari pakaian dan aksesoris yang ia gunakan seperti tas dan jas berbulu. Melalui konten di feed@awkarin, Karin menggambarkan dirinya sebagai wanita yang telah sukses menyelami dunia sosial media dengan baik dan hal ini didukung dengan captionnya "ain't nothing but a gangsta party". Tampilan atau visualisasi hedonisme yang ditampilkan Karin membuat dirinya memperoleh julukan influencer karena diikuti oleh 5,2 juta pengikut dan menjadi ikon fashion dalam dunia digital. 


\section{E. Unsur Hedonisme (Kegiatan) pada Laman@awkarin}

Hedonisme Awkarin dalam pesta ulang tahunnya merupakan unsur dari kegiatan yang menjadi salah satu unsur hedonism. Hal ini ditunjukan melalui potret diri saat ulang tahun yang diunggah tidak menggambarkan kegiatan sederhana di dalam rumah melainkan perayaan mewah dengan dukungan seluruh simbol kekayaan dan kemewahan di dalamnya. Secara eksternal, individu yang hedonis akan mengarahkan keseluruhan aktivitasnya pada kesenangan yang dirasakan atau adanya kepuasan yang ditunjukan sebagai bentuk kebahagiaan serta melakukan seleksi terhadap lingkungan terdekat seperti kelompok sosial yang sesuai dengan gaya hidupnya.

Gaya hidup hedonisme yang berasal dari faktor eksternal muncul tidak secara utuh dari dalam diri pribadi namun dikuatkan dengan pengaruh dari kelompok referensi (kelompok yang memberikan pengaruh secara langsung dan tidak langsung terhadap sikap individu). Kelompok referensi atau kelompok rujukan memiliki pengaruh yang besar pada keputusan yang diambil seseorang (Schiffman dan Kanuk, 2008: 34). Individu akan menjadikan kelompok rujukannya sebagai pertimbangan utama dalam menentukan keputusan dan berperilaku sehingga secara langsung individu akan membandingkan dirinya dalam mengevaluasi diri dan meyakini norma yang sesuai dengan dirinya (Loundon dan Bitta, 1984: 76).

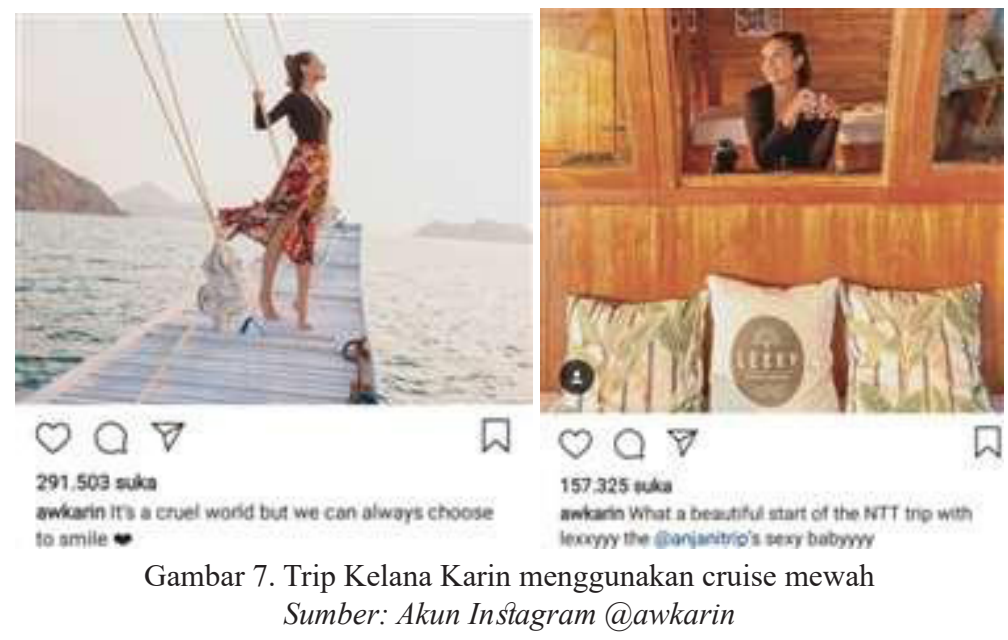

\section{F. Unsur Hedonisme (Minat) pada Laman @awkarin}

Karin melalui laman Instagramnya@awkarin menggambarkan minat hedonisnya dengan penekanan bahwa ia memiliki orientasi bekerja sekaligus berlibur di lokasi yang mewah. Hal ini tentu saja berimbas pada gambaran identitas diri yang semakin kuat pada dirinya bahwa ia adalah influencer atau selebgram sukses dan mapan dengan cara dan versinya sendiri. Pada laman Instagram @awkarin terdapat unggahan pada tanggal 16 Oktober 2019 yang menunjukan Karin sedang berlayar menggunakan cruise menuju Labuan Bajo untuk tujuan shooting konten Youtube nya. Kemewahan yang ditunjukkan oleh Awkarin sebenarnya merupakan hasil endorse oleh Anjani Trip kepada Awkarin sebagai penunjang transportasi Awkarin selama berkeliling Labuan Bajo. Hasil like yang diperoleh Awkarin pun tergolong tinggi pada postingan ini yaitu mencapai 260.781 like yang menunjukan bahwa para followernya menyukai unggahannya. Di kolom komentar muncul beberapa komentar positif mengenai Awkarin yaitu: “idola, calon mama yang sukses, dan tokoh idolaku”.

Susanto (2001: 33) menyatakan beberapa karakteristik individu yang memiliki gaya hidup hedonisme diantaranya lebih senang mengisi waktu luang di tempat yang santai dan kekinian seperti cafe. Bersenang-senang di kafe tidak selalu identik dengan minum-minuman beralkohol tetapi lebih pada menghabiskan waktu luang atau bersantai dengan teman dekat sekaligus menjadi tanda simbolis status sosial.

Karin dalam akunnnya @awkarin terlihat sering mengadakan sesi fotografi di mana dalam salah satu unggahannya, Karin berfoto dengan menonjolkan bagian bawah kebagian atas. Pengunggahan foto tersebut didukung dengan caption "looking down all of my haters, where hates have brought you now". Kalimat tersebut merupakan sebuah kalimat yang ditujukan Karin kepada seluruh hatersnya. Hal ini dilakukan oleh Karin karena ia pernah menjadi korban bully dari netizen yang tidak menyukainya. Pada awal tahun 2019, Karin dianggap influencer yang sangat buruk karena memberikan dampak negatif terhadap para generasi milenial yang gemar bermain sosial media.

Karakteristik gaya hidup hedonisme dapat dilihat dari berbagai aspek dan kriteria yang ada yaitu suka mencari perhatian, cenderung impulsif, kurang rasional, cenderung follower, mudah dipengaruhi teman, senang mengisi waktu luang di luar rumah seperti halnya yang dilakukan oleh Karin dan diunggahnya di laman akun pribadinya. Freud (dalam Gunawan, 2010: 35) menyatakan bahwa pengungkapan hedonisme berada pada fase ego formation atau fase di mana seseorang memberikan perhatian yang sangat tinggi terhadap dirinya sehingga akan sering merasa kagum terhadap dirinya. Berdasar pada unggahan Karin di Instagramnya, ia menunjukan rasa bangganya atas apa yang telah ia kerjakan dan hasilkan. 


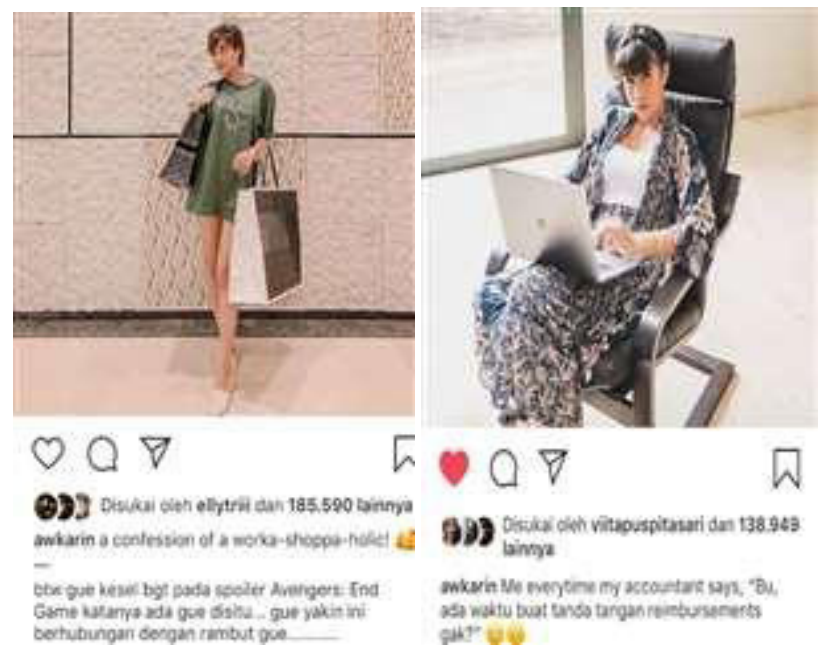

Gambar 8. Penggambaran diri Awkarin pada saat bekerja dan berbelanja Sumber: AkunInstagram @awkarin

Pada unggahannya, Karin menunjukan bahwa orang lain dapat melihat hasil dari kerja kerasnya sebagai pengusaha sukses yaitu dapat berbelanja berbagai barang yang menunjukan kelas sosialnya (sebagai simbol kesuksesan). Diamati selama satu tahun, Karin terlihat berlomba dengan influencer lain dalam hal mengunggah potret diri (selfie) atau dengan kawan penggunanya (wefie) dengan tujuan meningkatkan atensi publik yang dapat diunggah pada feed Instagram atau di instastories miliknya.

\section{KESIMPULAN}

Hasil penelitian menunjukan bahwa Karin melalui akun Instagramnya@awkarin telah membentuk identitas sosial secara virtual sesuai tujuan yang diinginkan. Karin membentuk identitasnya dengan menampilkan foto-foto yang mendukung nilai individu yang selama ini dianutnya, yaitu: menjadi diri apa adanya. Orientasi Personal yang ingin ditunjukan Karin melalui Instagramnya adalah dengan menjadi orang yang keren dan berani di mana hal ini tergambar jelas melalui foto yang diunggah, kalimat pada caption dan balasan atas komentar yang diberikan oleh netizen. Ekspresi diri yang ditampilkan melalui akun Instagramnya@awkarin menunjukan dirinya adalah pribadi yang open minded, setia dan memiliki solidaritas yang tinggi dengan teman. Nilai individu, Orientasi Personal dan Ekspresi diri merupakan tiga komponen identitas sosial yang tergambar secara nyata melalui unggahan di akun selebgram Awkarin.

Bentuk hedonisme yang ditampilkan di media sosial Instagram mencakup tiga hal, yaitu: Aktivitas, Minat dan Opini. Aktivitas hedonism yang ditunjukan Karin dalam feed Instagramnya menunjukan bahwa Karin memiliki banyak aktivitas di luar rumah, memiliki kebiasaan berbelanja barang mewah dan sering pergi bersama teman-temannya atau pasanganya ke kafe atau pusat perbelanjaan. Awkarin menunjukan minatnya pada barang branded yang digunakan atau dimiliki dan berkumpul di tempat hangout yang diperuntukan bagi kelas sosial menengah keatas. Awkarin tidak segan membalas komentar para netizen yang diperuntukan baginya baik yang pro maupun yang kontra. Hal ini menunjukan bahwa Karin menyadari apa yang dia unggah pasti akan memperoleh dukungan maupun sebaliknya dari mereka yang menjadi followers maupun mereka yang menjadi haters.

\section{DAFTAR PUSTAKA}

[1] Achsa,Hatmi. (2015). Representasi Diri dan Identitas Virtual Pelaku Roleplay Dalam Dunia Maya ('Permainan Peran’ Hallyu Star Idol K-Pop dengan Media Twitter). Paradigma, Volume 03 Nomor 03.

[2] Akira Aulia W., dan Mutia Rahmi Pratiwi. (2019). Etnografi Virtual pada Laman IG Stories sebagai Bentuk Komunikasi Interpersonal. Jurnal Audience: Jurnal Ilmu Komunikasi.

[3] Alwisol. (2011). Psikologi Kepribadian. Malang: UMM Press.

[4] Amstrong, Michael. (2003). Strategic Human Resource Management. Terjemahan Atit Cahayani. Jakarta: PT. Bhuana Ilmu Populer.

[5] Bate, S.P.(1997). "Whatever Happened to Organizational Anthropology? A Review of the Field Organizational Ethnography and Anthropological Studies". Human Relation.

[6] Bagus, Lorens. (2005). Kamus Filsafat. Jakarta: Gramedia Pustaka Utama.

[7] Ghufron, M. Nur \& Risnawati S. Rini. 2009. Teori-teori Psikologi. Yogyakarta: Arruzz Media. 
[8] Gunawan, Ary, H. (2010). Sosiologi Pendidikan Suatu Analisis Sosiologi Tentang Berbagai Problem Pendidikan. Jakarta: PT. Rineka Cipta.

[9] Hine, Christine. (2000). Virtual Ethnography. London, Thousand Oaks, New Delhi: SAGE Publications.

[10] Hurley, S.L. (1998). Consciousness in Action. Cambridge: Harvard University Press.

[11] Kozinets, R.V. (2002). "The Field Behind the Screen: Using Netnography for Marketing Research Online Communities" Journal of Marketing Research.

[12] Loundon, D.L. dan A.J.D. Bitta. (1984). Consumer Behavior. NewYork: McGraw-Hill Book Company

[13] Moleong, Lexi J. (2006). Metodologi Penelitian Kualitatif. Bandung: PT. Remaja Rosdakarya.

[14] Nasrullah, Rulli. (2014). Teori dan Riset Media Siber (Cybermedia). Jakarta : Kencana.

[15] Rahardjo, W., Silalahi, Y.B. (2007). Perilaku Hedonisme Pada Pria Metroseksual Serta Pendekatan Dan Strategi Yang Digunakan Untuk Mempengaruhinya. Pesat Volume 2. Jakarta: Universitas Gunadarma.

[16] Salam, Burhanuddin. (2000). Etika Individu Pola Dasar Filsafat Moral. Jakarta: Rineka Cipta.

[17] Schiffman L. dan Kanuk L. (2008). Perilaku Konsumen. Jakarta: PT. Indeks Perkasa

[18] Susanto (2001). Potret-Potret Gaya Hidup Metropolis. Jakarta : Penerbit Kompas

[19] Tajfel, H. (1982). Social Psychology of intergroup relations. Annual Review of Psychology, 33 (1), 1-39.

[20] Tajfel, H. \& Turner, J.. (1986). The Social Identity theory of intergroup behavior. In S. Worchel, \& W.G. Austin (Eds.). Psychology of intergroup relations (pp.7-24). (2 ${ }^{\text {nd }}$ ed). Chicago. Nelson-Hall

[21] Tilley, J.J. (2012). Hedonism. USA: Indiana University - Purdue University Indianapolis (IUPUI).

[22] Van Dijk. (2013). The Culture of Connectivity: A Critical History of Social Media. UK: Oxford University Press.

[23] We Are Social (2019). Most Active Social Media Platforms. WeAreSocial.Net. https://www.slideshare.net/Data. Reportal/digital-2019-indonesia-january- 2019-v01

[24] Widyarini, M. M. Nilam, Dra, Msi. (2009). Seri Psikologi Populer: Kunci Pengembangan Diri. Jakarta : PT Elex Media Komputindo.

[25] Wijayanti, Mita. (2018). Hedonisme sebagai Identitas Pengguna Media Sosial Instagram di Bandarlampung. Skripsi Ilmu Komunikasi. Universitas Bandar Lampung. 
